\title{
Development and Acceptability of Multi-Purpose Electrical Circuit Demonstration Trainer
}

\author{
Warlito D. Antonio \\ Isabela State University, Angadanan Isabela, Philippines, antoniowarlito@gmail.com
}

\begin{abstract}
The research was aimed at ascertaining the acceptability of the Isabela State University 's established Multi-Purpose Electrical Circuit Demonstration Trainer. The study made use of descriptive analysis using instructors teaching courses in electrical technology and students from the Isabela State University's three campuses, namely: Angadan Campus, Cauayan Campus, and Ilagan Campus. These two groups of respondents used a 20 -item questionnaire with five items per section to assess the acceptability of the established demonstration trainer with respect to its design, construction, functionality and safety. The developed Multi-Purpose Electrical Circuit Demonstration Trainer is thus patented, replicated and adopted for use by other universities and colleges offering courses in electrical technology.
\end{abstract}

Key words: acceptability, development, demonstration trainer, electrical circuit, multi-purpose

\section{INTRODUCTION}

Lasam stressed that any state-run college or university 's technology education program as an integral part of the Philippine education system is responsible for the level of formal education that focuses on the creation of skilled workers and technicians with adequate skills, attitudes and skills for different types and technology levels. Relative to the scenario of thepresent educational system as well as the need for our country to become globally competitive, students should be trained to the utmost of their capabilities through the use of modern instructional materials and models which plays a vital role in the attainment of the goals and objectives of technology education.In classroom situation, exposure of students to actual laboratory activities is very limited. Thus, this study was conceptualized in order to upgrade the knowledge and skills of the students. Aware of this problem, the researcher was challenged to undertake a feasibility study focused on the acceptability of the developed multi-purpose electrical circuit demonstration trainer. This trainer was designed to enable the teachers in Electrical Technology to effectively teach the different kinds of electrical circuits used in building wiring installation, and electrical appliance servicing. The project is envisioned to be easy to operate, suited to the level of the students, and responsive to the current demands of the shop and the industrial sector.The study specifically aims to seek answers to the following questions: a) how do the instructor and student respondents assess the acceptability of the developed multi-purpose electrical circuit demonstration trainer with respect to its design, construction, functionality and safety? b) is there a significant difference between the evaluation of the two groups of respondents on the design, construction, functionality and safety of the developed demonstration trainer?, and, c) are there significant differences among the evaluation of instructor respondents on the acceptability of the demonstration trainer when they are grouped according to age, civil status, and number of years teaching Electrical Technology Courses? The input-process-output model was used in this study. In the development of a Multi-Purpose Electrical Circuit Demonstration Trainer. The input consists of the Electrical Technology students 'psychomotor results, researchers' ideas / concepts, books and papers, supplies and resources, tools and equipment, and measuring and test instruments. The cycle deals with the trainer's planning, designing, constructing, reviewing, revising and presentation. The output is the developed Multi-Purpose Electrical Circuit Demonstration Trainer. On the other hand, the second and final phase of the study is focused on determining the acceptability of the developed trainer. The feedback consists of two groups of respondents, namely teachers of electrical technology and freshman students at The three campuses of Isabela State University that evaluated the trainer in terms of architecture, construction, functionality and safety. The process involves determining the trainer's acceptability built in terms of design, construction, functionality, and safety. The performance is the appropriate electrical circuit test trainer for multipurpose.

\section{RESEARCH METHODOLOGY}

The research analysis used the method of description science. This research design was employed by using a questionnaire to determine the trainer's acceptability in terms of design, construction, functionality, and safety.These papers [16], [22], and [28] were considered by the researcher in crafting the approach on implementation of the trainer.The respondents used in the evaluation of the trainer were the Electrical Technology students and instructors of the Isabela State University Angadanan, Cauayan, and Ilagan Campuses. The freshman Electrical Technology students at Isabela State University-Angadanan Campus were utilized in the construction of the trainer. The respondents for the validation/evaluation of the trainer were the freshman Electrical Technology students and the Electrical Technology instructors/professors of the Isabela State University campuses offering Electrical Technology courses.Twenty (20) Electrical Technology Instructors from the three campus of Isabela State University namely, Angadanan, Cauayan and Ilagan, were utilized as instructor 
respondents in this study. No randomization was done. The instructors were taken as respondents through purposive sampling.A semi-structured questionnaire consisting of two sections was the main instrument used for collecting the data. Part I deals with the profile of the respondents consisting of age, civil status and number of years in teaching subjects relevant to electrical technology. Part II deals with the requirements for assessing the established trainer's acceptability in terms of design, construction, functionality and health. It makes use of a 5-point Likerttype questionnaire designed to determine the acceptability of the trainer. Using the statistical methods below: mean, t-test for independent samples, and ANOVA, the data collected were collected and analyzed after the questionnaires were administered and recalled.

\section{RESULTS AND DISCUSSIONS}

\subsection{Evaluation of Respondents on the Trainer}

The table 1 below revealed the acceptability assessment of the built multi-purpose electrical circuit demonstration trainer in terms of design, construction, functionality and safety by the teacher and student respondents.

Table 1:Mean Evaluations of the Instructor and Student Respondents (Design)

\begin{tabular}{|l|c|c|c|c|}
\hline Design & $\begin{array}{c}\text { Instruct } \\
\text { ors }\end{array}$ & $\begin{array}{c}\text { Qualitative } \\
\text { Description }\end{array}$ & Students & $\begin{array}{c}\text { Qualitative } \\
\text { Description }\end{array}$ \\
\hline $\begin{array}{l}\text { 1. The design } \\
\text { is suited for } \\
\text { tertiary } \\
\text { students. }\end{array}$ & 4.900 & SA & 4.851 & SA \\
\hline $\begin{array}{l}\text { 2. Parts/suppli } \\
\text { es/materials } \\
\text { of the } \\
\text { trainer are } \\
\text { available in } \\
\text { electrical } \\
\text { stores. }\end{array}$ & 5.000 & SA & 4.872 & SA \\
\hline $\begin{array}{l}\text { 3. The } \\
\text { component } \\
\text { parts of the } \\
\text { trainer are } \\
\text { strategically } \\
\text { located. }\end{array}$ & 4.900 & SA & 4.787 & SA \\
\hline $\begin{array}{l}\text { 4. The } \\
\text { component } \\
\text { parts of the } \\
\text { trainer are } \\
\text { visible. }\end{array}$ & 4.650 & SA & 4.638 & SA \\
\hline $\begin{array}{l}\text { 5. The } \\
\text { component } \\
\text { parts of the } \\
\text { trainer are } \\
\text { replaceable. }\end{array}$ & 4.900 & SA & 4.830 & SA \\
\hline $\begin{array}{l}\text { Grand } \\
\text { Mean }\end{array}$ & 4.870 & Very Much & 4.796 & Very Much \\
\hline
\end{tabular}

SA - Strongly Agree

Data show that both instructor and student respondents evaluated the trainer to be very much acceptable with regard to its design. This is evidenced by the high mean ratings ranging from 4.638 to 5.000 for the two groups of respondents. This could mean that the said trainer was constructed with a design suited for tertiary students and that its parts, supplies, materials are available in local electrical stores. Further, the components parts of the trainer are strategically located, visible and replaceable.

Findings show that the multi-purpose electrical circuit demonstration trainer is within the standards of design for instructional materials. This indicates that the trainer could be utilized by both students and instructors in performing activities related to electricity that will help develop students' psychomotor skills.

Table 2:Mean Evaluations of the Instructor and Student Respondents (Construction)

\begin{tabular}{|c|c|c|c|c|}
\hline Construction & $\begin{array}{c}\text { Instructo } \\
\text { rs }\end{array}$ & $\begin{array}{l}\text { Qualitative } \\
\text { Description }\end{array}$ & Students & $\begin{array}{l}\text { Qualitative } \\
\text { Description }\end{array}$ \\
\hline $\begin{array}{l}\text { 1. The set-up } \\
\text { of the } \\
\text { mock-up is } \\
\text { well- } \\
\text { organized. }\end{array}$ & 4.900 & SA & 4.787 & SA \\
\hline $\begin{array}{l}\text { 2. The } \\
\text { cabinet/box } \\
\text { containing } \\
\text { the trainer is } \\
\text { properly } \\
\text { built. }\end{array}$ & 4.850 & SA & 4.809 & SA \\
\hline $\begin{array}{l}\text { 3. The } \\
\text { attachments } \\
\text { of the } \\
\text { component } \\
\text { parts are } \\
\text { neatly } \\
\text { arranged. }\end{array}$ & 5.000 & SA & 4.723 & SA \\
\hline $\begin{array}{l}\text { 4. All the } \\
\text { attachments } \\
\text { are } \\
\text { purposeful } \\
\text { and } \\
\text { functional. }\end{array}$ & 5.000 & SA & 4.745 & SA \\
\hline $\begin{array}{l}\text { 5. The mock- } \\
\text { up is } \\
\text { portable. }\end{array}$ & 4.700 & SA & 4.681 & SA \\
\hline $\begin{array}{l}\text { Grand } \\
\text { Mean }\end{array}$ & 4.890 & $\begin{array}{l}\text { Very Much } \\
\text { Acceptable }\end{array}$ & 4.749 & $\begin{array}{l}\text { Very Much } \\
\text { Acceptable }\end{array}$ \\
\hline
\end{tabular}

\section{SA - Strongly Agree}

It could be noticed from the table that both respondents strongly agree with all the items on the questionnaire as suggested for instructors and students respectively by the overall mean of 4,890 and 4,749.

Data (table 2) show that both instructor and student respondents evaluated the trainer to be very much acceptable with regard to its construction. This is evidenced by the high mean ratings ranging from 4.681 to 5.000 for the two groups of respondents. This could mean that the said trainer was constructed with a well-organized mock-up and that the cabinet/box containing it was properly built. Further, the attachment of the components parts was neatly done, 
Warlito D. Antonio, International Journal of Advanced Trends in Computer Science and Engineering, 9(1.3), 2020, 208- 214

purposeful, and functional. And finally, the mock-up is portable.

Findings show that the multi-purpose electrical circuit trainer is within the standards for the construction of instructional materials. This indicates that the trainer could be utilized by both students and instructors since it was constructed based on the need of students for effective and efficient delivery of instruction.

Table 3: Mean Evaluations of the Instructor and Student Respondents (Functionality)

\begin{tabular}{|c|c|c|c|c|}
\hline Functionality & $\begin{array}{l}\text { Instru } \\
\text { ctors }\end{array}$ & $\begin{array}{l}\text { Qualitative } \\
\text { Description }\end{array}$ & Students & $\begin{array}{l}\text { Qualitative } \\
\text { Description }\end{array}$ \\
\hline $\begin{array}{l}\text { 1. The trainer is } \\
\text { effective for } \\
\text { instructional } \\
\text { use. }\end{array}$ & 5.000 & SA & 4.830 & SA \\
\hline $\begin{array}{l}\text { 2. The trainer } \\
\text { can perform } \\
\text { several } \\
\text { activities/oper } \\
\text { ations. } \\
\end{array}$ & 5.000 & SA & 4.894 & SA \\
\hline $\begin{array}{l}\text { 3. The trainer } \\
\text { can perform } \\
\text { the desired } \\
\text { activities. }\end{array}$ & 5.000 & SA & 4.745 & SA \\
\hline $\begin{array}{l}\text { 4. The trainer is } \\
\text { easy to } \\
\text { operate/manip } \\
\text { ulate. } \\
\end{array}$ & 4.950 & SA & 4.723 & SA \\
\hline $\begin{array}{l}\text { 5. The trainer } \\
\text { can perform } \\
\text { simple to } \\
\text { complex } \\
\text { activities. } \\
\end{array}$ & 5.000 & SA & 4.787 & SA \\
\hline $\begin{array}{l}\text { Grand } \\
\text { Mean }\end{array}$ & 4.990 & $\begin{array}{l}\text { Very Much } \\
\text { Acceptable }\end{array}$ & 4.796 & $\begin{array}{l}\text { Very Much } \\
\text { Acceptable }\end{array}$ \\
\hline
\end{tabular}

SA - Strongly Agree

Data show that both instructor and student respondents evaluated the trainer to be very much acceptable with regard to its functionality (table 3). This is evidenced by the high mean ratings ranging from 4.723 to 5.000 for the two groups of respondents. This could mean that the said trainer is effective for instructional use and can be used for performing several activities or operations in Electrical Technology subjects. Further, the two sets of respondents strongly agree that the said trainer is easy to operate or manipulate and can be used for performing simple to complex activities.

The high ratings of the two sets of respondents could be attributed to the fact that they adhere to the idea that improvised gadgets or devices could solve the problems of inadequacy of instructional materials in their shops.
Table 4:Mean Evaluations of the Instructor and Student Respondents (Safety)

\begin{tabular}{|l|c|c|c|c|}
\hline \multicolumn{1}{|c|}{ Safety } & $\begin{array}{c}\text { Instruct } \\
\text { ors }\end{array}$ & $\begin{array}{c}\text { Qualitative } \\
\text { Description }\end{array}$ & Students & $\begin{array}{c}\text { Qualitative } \\
\text { Description }\end{array}$ \\
\hline $\begin{array}{l}\text { 1. The mock- } \\
\text { up } \\
\text { stand/frame/ } \\
\text { base is safe } \\
\text { to use. }\end{array}$ & 4.800 & SA & 4.894 & SA \\
\hline $\begin{array}{l}\text { 2. The } \\
\text { component } \\
\text { parts are } \\
\text { designed for } \\
\text { 220 Volt } \\
\text { Alternating } \\
\text { Current } \\
\text { (VAC) } \\
\text { source. }\end{array}$ & 5.000 & SA & 4.851 & SA \\
\hline $\begin{array}{l}\text { 3. The mock- } \\
\text { up is } \\
\text { equipped } \\
\text { with a safety } \\
\text { device. }\end{array}$ & 4.750 & SA & 4.809 & SA \\
\hline $\begin{array}{l}\text { 4. The } \\
\text { installation } \\
\text { of the } \\
\text { circuits is } \\
\text { safe for } \\
\text { demonstrati } \\
\text { on. }\end{array}$ & 5.000 & SA & & \\
\hline $\begin{array}{l}\text { 5. The size of } \\
\text { the } \\
\text { connecting } \\
\text { wires/leads } \\
\text { conforms to } \\
\text { standards. }\end{array}$ & 4.850 & SA & 4.809 & SA \\
\hline $\begin{array}{l}\text { Mrand } \\
\text { Mean }\end{array}$ & 4.880 & Very Much & 4.855 & Very Much \\
Acceptable & & & \\
\hline
\end{tabular}

SA - Strongly Agree

Data reveal that both instructor and student respondents evaluated the trainer to be very much acceptable with regard to its safety (table 4). This is evidenced by the high mean ratings ranging from 4.750 to 5.000 for the two groups of respondents.

This may mean that the said trainer is safe to use for both instructors and students as it is made of stand / frame / base that is safe to use and sections of the components are built for 220 volt alternating current.The two groups of respondents also strongly agree that the said trainer is fitted with a safety device and that the circuit installation is safe for demonstration purposes. The size of the connecting wires / leads also complies with standards.

\subsection{Analysis on the Evaluation of the Respondents}

Table 5 below shows the substantial difference in the design, construction, functionality and safety of the built multipurpose electric circuit demonstration trainer between the assessment of the teacher respondents and the student respondents. 
Warlito D. Antonio, International Journal of Advanced Trends in Computer Science and Engineering, 9(1.3), 2020, 208- 214

Table 5:Summary of Significant Difference Existing between the Evaluationsof the Instructor and Student Respondents

\begin{tabular}{|c|c|c|c|c|}
\hline \multirow{2}{*}{ Components } & \multicolumn{2}{|c|}{ Mean } & \multirow{2}{*}{$\begin{array}{l}\text { Computed } \\
\text { t-Value }\end{array}$} & \multirow{2}{*}{ Remarks } \\
\hline & Instructors & Students & & \\
\hline Design & 4.870 & 4.796 & 1.048 & $\begin{array}{c}\text { Not } \\
\text { Significant }\end{array}$ \\
\hline Construction & 4.890 & 4.749 & 1.670 & $\begin{array}{c}\text { Not } \\
\text { Significant }\end{array}$ \\
\hline Functionality & 4.990 & 4.796 & 2.298 & Significant \\
\hline Safety & 4.880 & 4.855 & 0.419 & $\begin{array}{c}\text { Not } \\
\text { Significant }\end{array}$ \\
\hline
\end{tabular}

It could be seen in the table that the two groups of respondents did not differ significantly in their evaluation of the acceptability of the developed multi-purpose electrical circuit trainer as to its design, construction and safety as evidenced by the lower computed t-values of $1.048,1.670$, and 0.419 , respectively, as compared with the critical t-value of 1.998 for 65 degrees of freedom at 0.05 level of significance. Therefore, the null hypothesis that there is no substantial difference between the evaluation of the respondents of the teacher and the respondents of the students on the design, construction and safety of the trainer built is acknowledged.

The non-significance of the differences in the ratings of the two groups of respondents could mean that they strongly agree that the developed trainer is very much acceptable as to its design, construction and safety. It could also be interpreted that both perceived the acceptability of the trainer on an almost equal level. Further, it could mean that it is acceptable as an instructional material which could enhance the students' psychomotor skills and performance.

Both groups of respondents agree that the trainer is very much acceptable as to its functionality as evidenced by the very high mean scores registered by both groups. However, when the difference in their mean ratings was tested using ttest for independent samples, it came out that there is a significant difference in their ratings. The group of instructors rated the acceptability of the trainer higher than their student counterparts. The lower ratings of students could be attributed to their lack and length of exposure to improvised gadgets as compared to the higher ratings of the instructors who have been teaching the course for quite sometimes.

\subsection{Analysis on the Evaluation of the Respondents in Terms of their Profile}

The table 6 below revealed the significant differences among the evaluation of instructor respondents on the acceptability of the demonstration trainer when they are grouped according to age, civil status and number of years in teaching Electrical Technology Courses.
Table 6: Results on the Evaluation of the Instructor Respondents on the Acceptability of the Trainer (Profile)

\begin{tabular}{|c|c|c|c|c|c|c|}
\hline $\begin{array}{l}\text { Variabl } \\
\text { es }\end{array}$ & $\begin{array}{c}\text { Grouping } \\
\mathrm{s}\end{array}$ & Mean & df & $\begin{array}{l}\text { Comp } \\
\text { uted } \\
\text { Value }\end{array}$ & $\begin{array}{l}\text { Critic } \\
\text { al } \\
\text { Value }\end{array}$ & Remarks \\
\hline \multirow[t]{3}{*}{ Age } & $\begin{array}{c}41 \& \\
\text { above }\end{array}$ & 4.815 & \multirow{3}{*}{$\begin{array}{l}2 \\
\& \\
64\end{array}$} & \multirow[t]{3}{*}{3.000} & \multirow[t]{3}{*}{3.138} & \multirow{3}{*}{$\begin{array}{c}\text { Not } \\
\text { Significa } \\
\text { nt }\end{array}$} \\
\hline & $31-40$ & 4.960 & & & & \\
\hline & $21-30$ & 5.000 & & & & \\
\hline \multirow{2}{*}{$\begin{array}{l}\text { Civil } \\
\text { Status }\end{array}$} & Married & 4.859 & \multirow[t]{2}{*}{65} & \multirow[t]{2}{*}{0.682} & \multirow[t]{2}{*}{1.998} & \multirow{2}{*}{$\begin{array}{c}\text { Not } \\
\text { Significa } \\
\text { nt }\end{array}$} \\
\hline & Single & 4.933 & & & & \\
\hline \multirow{3}{*}{$\begin{array}{l}\text { Number } \\
\text { of } \\
\text { Years } \\
\text { in } \\
\text { Teachin } \\
\text { g } \\
\text { Electric } \\
\text { al } \\
\text { Technol } \\
\text { ogy } \\
\text { Courses }\end{array}$} & $\begin{array}{r}21 \& \\
\text { above }\end{array}$ & 5.000 & \multirow{3}{*}{$\begin{array}{l}2 \\
\& \\
64\end{array}$} & \multirow{3}{*}{1.875} & \multirow{3}{*}{3.138} & \multirow{3}{*}{$\begin{array}{c}\text { Not } \\
\text { Significa } \\
\text { nt }\end{array}$} \\
\hline & $11-20$ & 4.878 & & & & \\
\hline & $1-10$ & 4.900 & & & & \\
\hline
\end{tabular}

It could be seen in the table that there are no significant differences in the evaluation of the teacher respondents on the acceptability of the trainer with regard to its design when grouped according to age, civil status, and number of years teaching the course as evidenced by the lower computed values of $3.000,0.682$ and 1.875 , respectively, as compared to the critical values of 3.138 for 2 and 64 degrees of freedom and 1.998 for 65 degrees of freedom at 0.05 level of significance. Hence, the null hypothesis is accepted.

This could mean that regardless of age, civil status, and number of years teaching Electrical Technology courses, the respondents all agree that the developed circuit trainer is very much acceptable as to its design as a product of proper planning and research.

Table 7: Results on the Evaluations of the Instructor Respondents on the Acceptability of the Trainer (Profile)

\begin{tabular}{|c|c|c|c|c|c|c|}
\hline $\begin{array}{c}\text { Variab } \\
\text { les }\end{array}$ & Groupings & Mean & df & $\begin{array}{c}\text { Comp } \\
\text { uted } \\
\text { Value }\end{array}$ & $\begin{array}{c}\text { Critical } \\
\text { Value }\end{array}$ & $\begin{array}{c}\text { Remar } \\
\text { ks }\end{array}$ \\
\hline \multirow[t]{3}{*}{ Age } & $\begin{array}{c}41 \& \\
\text { above }\end{array}$ & 4.846 & \multirow{3}{*}{$\begin{array}{l}2 \\
\& \\
64\end{array}$} & \multirow[t]{3}{*}{1.423} & \multirow[t]{3}{*}{3.138} & \multirow{3}{*}{$\begin{array}{c}\text { Not } \\
\text { Signif } \\
\text { icant }\end{array}$} \\
\hline & $31-40$ & 4.960 & & & & \\
\hline & $21-30$ & 5.000 & & & & \\
\hline \multirow{2}{*}{$\begin{array}{l}\text { Civil } \\
\text { Status }\end{array}$} & Married & 4.894 & \multirow[t]{2}{*}{65} & \multirow[t]{2}{*}{0.249} & \multirow[t]{2}{*}{1.998} & \multirow{2}{*}{$\begin{array}{c}\text { Not } \\
\text { Signif } \\
\text { icant }\end{array}$} \\
\hline & Single & 4.867 & & & & \\
\hline \multirow{3}{*}{$\begin{array}{l}\text { Numb } \\
\text { er of } \\
\text { Years } \\
\text { in } \\
\text { Teachi } \\
\text { ng } \\
\text { Electri } \\
\text { cal } \\
\text { Techn } \\
\text { ology } \\
\text { Cours } \\
\text { es }\end{array}$} & $\begin{array}{c}21 \& \\
\text { above }\end{array}$ & 5.000 & \multirow[b]{3}{*}{$\begin{array}{l}2 \\
\& \\
64\end{array}$} & \multirow[b]{3}{*}{5.211} & \multirow[b]{3}{*}{3.138} & \multirow{3}{*}{$\begin{array}{l}\text { Very } \\
\text { Signif } \\
\text { icant }\end{array}$} \\
\hline & $11-20$ & 4.800 & & & & \\
\hline & $1-10$ & 5.000 & & & & \\
\hline
\end{tabular}

It could be seen in the table 7 that age and civil status did not cause any variation in the evaluation of the instructor 
respondents on the acceptability of the trainer as to its construction. This is evidenced by the lower computed values as compared with the critical values at 0.05 level of significance. This could mean that regardless of age and civil status, the respondents evaluated the trainer to be properly built and well-organized. On the other hand, when the instructor respondents were grouped according to number of years teaching Electrical Technology courses, their evaluation on the acceptability of the circuit trainer differed significantly. This is supported by the higher computed t-value of 5.211 as compared with the critical tvalue of 3.138 at 2 and 64 degrees of freedom at 0.05 level of significance. That led to the dismissal of the null hypothesis. Therefore, there is a substantial difference in the evaluation of teacher respondents as to the trainer's acceptability with respect to its construction when grouped according to the number of years of Electrical Technology teaching.

Further analysis of the data in Table 7 shows that those teaching the course for more than 20 years and those who have taught the subject for at most ten years evaluated the acceptability of the circuit trainer with regard to its construction with a mean rating of 5.000, interpreted as very much acceptable. Those who have been teaching the course from 11-20 years registered a mean rating of 4.800 which is still interpreted as very much acceptable. However, when the mean differences of the three groups were tested through analysis of variance, significant differences existed in their ratings, implying that they assessed the construction of the said trainer differently.

In an interview conducted with the instructor respondents, it was noted that most of them are presently enrolled in their graduate programs and are conceptualizing a similar study. Thus, they see that the construction of the trainer could still be improved.

Table 8:Results on the Evaluations of the Instructor Respondents on the acceptability of the Trainer (Selected Variable)

\begin{tabular}{|c|c|c|c|c|c|c|}
\hline Variables & $\begin{array}{c}\text { Groupin } \\
\text { gs }\end{array}$ & Mean & $\mathrm{df}$ & $\begin{array}{l}\text { Comput } \\
\text { ed } \\
\text { Value }\end{array}$ & $\begin{array}{l}\text { Critical } \\
\text { Value }\end{array}$ & $\begin{array}{c}\text { Remar } \\
\text { ks }\end{array}$ \\
\hline \multirow{4}{*}{ Age } & $41 \&$ & 5.000 & \multirow{4}{*}{$\begin{array}{l}2 \\
\& \\
64\end{array}$} & \multirow{4}{*}{1.500} & \multirow{4}{*}{3.138} & \multirow{4}{*}{$\begin{array}{l}\text { Not } \\
\text { Signif } \\
\text { icant }\end{array}$} \\
\hline & above & & & & & \\
\hline & $31-40$ & 4.960 & & & & \\
\hline & $21-30$ & 5.000 & & & & \\
\hline \multirow{2}{*}{$\begin{array}{l}\text { Civil } \\
\text { Status }\end{array}$} & Married & 4.988 & \multirow[t]{2}{*}{65} & \multirow[t]{2}{*}{0.429} & \multirow[t]{2}{*}{1.998} & \multirow{2}{*}{$\begin{array}{c}\text { Not } \\
\text { Signif } \\
\text { icant }\end{array}$} \\
\hline & Single & 5.000 & & & & \\
\hline \multirow{4}{*}{$\begin{array}{l}\text { Number } \\
\text { of Years } \\
\text { in } \\
\text { Teaching } \\
\text { Electrical } \\
\text { Technolo } \\
\text { gy } \\
\text { Courses }\end{array}$} & $\begin{array}{c}21 \& \\
\text { above }\end{array}$ & 5.000 & \multirow{4}{*}{$\begin{array}{c}2 \\
\& \\
64\end{array}$} & \multirow{4}{*}{0.500} & \multirow{4}{*}{3.138} & \multirow{4}{*}{$\begin{array}{c}\text { Not } \\
\text { Signif } \\
\text { icant }\end{array}$} \\
\hline & $11-20$ & 4982 & & & & \\
\hline & & & & & & \\
\hline & $1-10$ & 5.000 & & & & \\
\hline
\end{tabular}

It could be gleaned from the table that there is no significant difference in the evaluation of the teacher respondents on the acceptability of the circuit trainer with regard to its functionality when grouped according to age, civil status, and number of years teaching the course. This is evidenced by the lower computed values of $1.500,0.429$ and 0.500 , respectively, as compared to the critical values of 3.138 for 2 and 64 degrees of freedom and 1.998 for 65 degrees of freedom at 0.05 level of significance. Hence, the null hypothesis is accepted.

This could mean that regardless of age, civil status, and numbers of years teaching Electrical Technology courses, the respondents all agree that the developed circuit trainer is very much acceptable as to its functionality. The finding could be attributed to the fact that the said trainer was properly planned and constructed to serve the purpose for which it was constructed, that is, to enhance the development of students' psychomotor skills in the shop.

Table 9:Results on the Evaluation of the Instructor Respondents on the Acceptability of the Trainer (Selected Variables)

\begin{tabular}{|c|c|c|c|c|c|c|}
\hline $\begin{array}{l}\text { Variab } \\
\text { les }\end{array}$ & $\begin{array}{c}\text { Grouping } \\
\mathrm{s}\end{array}$ & Mean & df & $\begin{array}{c}\text { Compu } \\
\text { ted } \\
\text { Value } \\
\end{array}$ & $\begin{array}{c}\text { Critical } \\
\text { Value }\end{array}$ & $\begin{array}{c}\text { Remar } \\
\text { ks }\end{array}$ \\
\hline \multirow[t]{3}{*}{ Age } & $\begin{array}{c}41 \& \\
\text { above }\end{array}$ & 4.846 & \multirow{3}{*}{$\begin{array}{l}2 \\
\& \\
64\end{array}$} & \multirow[t]{3}{*}{0.889} & \multirow[t]{3}{*}{3.138} & \multirow{3}{*}{$\begin{array}{c}\text { Not } \\
\text { Signifi } \\
\text { cant }\end{array}$} \\
\hline & $31-40$ & 4.960 & & & & \\
\hline & $21-30$ & 4.900 & & & & \\
\hline \multirow{2}{*}{$\begin{array}{l}\text { Civil } \\
\text { Status }\end{array}$} & Married & 4.859 & \multirow[t]{2}{*}{65} & \multirow[t]{2}{*}{1.300} & \multirow[t]{2}{*}{1.9834} & \multirow{2}{*}{$\begin{array}{c}\text { Not } \\
\text { Signifi } \\
\text { cant }\end{array}$} \\
\hline & Single & 5.000 & & & & \\
\hline \multirow{3}{*}{$\begin{array}{l}\text { Numb } \\
\text { er of } \\
\text { Years } \\
\text { in } \\
\text { Teachi } \\
\text { ng } \\
\text { Electri } \\
\text { cal } \\
\text { Techn } \\
\text { ology } \\
\text { Cours } \\
\text { es }\end{array}$} & $\begin{array}{c}21 \& \\
\text { above }\end{array}$ & 5.000 & \multirow[b]{3}{*}{$\begin{array}{l}2 \\
\& \\
64\end{array}$} & \multirow[b]{3}{*}{3.762} & \multirow[b]{3}{*}{3.138} & \multirow[b]{3}{*}{$\begin{array}{c}\text { Signifi } \\
\text { cant }\end{array}$} \\
\hline & $11-20$ & 4.800 & & & & \\
\hline & $1-10$ & 4.967 & & & & \\
\hline
\end{tabular}

Data show that age and civil status did not cause any significant difference in the evaluation of the instructor respondents on the acceptability of the trainer with regard to its safety. This is evidenced by the lower computed values as compared with the critical values at 0.05 level of significance. This could mean that regardless of age and civil status, the respondents evaluated the trainer to be safe for use by both instructors and students. On the other hand, when the instructor respondents were grouped according to number of years teaching Electrical Technology courses, their evaluation on the acceptability of the trainer with regard to its safety differed significantly as supported by the higher computed t-value of 3.762 as compared with the critical t-value of 3.138 at 2 and 64 degrees of freedom at 0.05 level of significance. This led to the rejection of the null hypothesis. There is, therefore, a significant difference inthe evaluation of instructor respondents on the acceptability of the trainer with regard to its safety when they are grouped according to number of years in teaching Electrical Technology courses. 
Further analysis of the data in Table 9 shows that those teaching the course for more than 20 years and those who taught the subject for at most ten years evaluated the acceptability of the circuit trainer with regard to its construction with mean ratings of 5.000 and 4.967 , respectively, both interpreted as very much acceptable. Those who have been teaching the course from 11-20 years registered a mean rating of 4.800 which is still interpreted as very much acceptable. However, when the mean differences of the three groups were tested through analysis of variance, significant differences existed in their ratings, implying that they see the safety of the said circuit trainer differently. Moreover, the significant difference on the safety of the developed trainer can be credited to the limited exposure of the faculty to such training device. The researcher came to know about this when he interviewed the faculty respondents during the validation of the trainer.

\section{CONCLUSION}

The electrical circuit trainer designed for multi-purpose demonstration is found to be highly appropriate in design , construction, functionality and safety.In their evaluation the instructor and student respondents disagreed as to the demonstration trainer's acceptability as to its features.However, they did not differ in evaluating the acceptability as to its design, construction, and safety.The instructor respondents did not differ in the evaluation of the acceptability of the demonstration trainer with regard to design and functionality regardless of their age, civil status, and number of years teaching Electrical Technology courses. However, they differed in their evaluation of the acceptability of the trainer with regard to its construction and safety according to the number of years they have been teaching Electrical Technology courses.

\section{FUTURE WORKS}

1. The developed Multi-Purpose Electrical Circuit Demonstration Trainer will be patented, replicated and accepted for use by other Electrical Technology courses offering colleges and universities.

2. An experimental study should be performed to assess the trainer's efficacy in enhancing the psychomotor skills and efficiency of Electrical Technology students.

3. Administration could allocate more funding to develop and validate improvised gadgets to improve academic and psychomotor performance for students.

4. School authorities should encourage the improvisation of instructional materials in the other technology areas.

5. Further studies should be conducted to come up with a more effective demonstration trainer with improved design, construction, functionality, and safety features.

\section{REFERENCES}

1. Calderon, Jose F. and Gonzales, 1993. Expectation C. Methods of Research and Thesis
Writing.Mandaluyong City, Philippines, National Book Store.

2. Camarao, Fedesario. 1991.Technology Education in the Philippines. Philippine National Book Store, Inc.

3. Lardizabal, A.S. et al. 1997.Methods and Principles of Teaching, Philippines, Manila: Phoenix Press, Inc.

4. Palmquist, Roland E. 1980.Electrical Course for Apprentices and Set-up. Chicago: American Society Third Edition.

5. Palmquist, Roland E. Questions and Answers for Electricians Examination. National Book Store.

6. Azares, Efren S. and Recana, Cirilo B. 1999. Effective Technology and Home Economics, Series III, Electricity for Third Year High School. Adriana Publishing Co., Inc.

7. Bangayan, Oscar G. and Cristobal, Romel B. 2006. Development and Design of 14-ich Analog Color Television Receiver Trainer: An Instructional Model. Isabela State University, Research and Development Journal, Volume II, Number 1.

8. Cabardo, Adelina V. 2003. Computer Assisted Learning (CAL) Readiness of Tomas Opus Normal College, A Research Report, TONC Journal of Education, Volume 1, Number 1, November.

9. Agraam, Melecio"Improvised Motor Control Circuit Demonstration Panel: A Technical Feasibility Study, NVSPC, 1995.

10. Andaya, Floro T. "AC Machine Circuit Trainer: A Technical Feasibility Study.” MIST, Marikina City 2002.

11. Alcantara, Felric. Video Cassette Recorder Trainer. DMMMSU, San Fernando, La Union, 1997

12. Bernardo, Triny G. "Infrared Floodlight Detector Trainer: A Technical Feasibility Study." Marikina Institute of Technology, Marikina City 2000.

13. Bungag, Joel Q. "Four Stroke Cycle, FourCylinder Gasoline Engine Trainer." A Masteral Thesis, MIST, Marikina City, 2003.

14. Cruz, Dominador A. "Technology and Home Economics Instruction with the Public Secondary School of La Union." A Masteral Thesis, Lorna Collages, San Fernando City, La Union 2000.

15. Dalay, Mario S. The Effectiveness of the Modularized Basic electrical Circuit Trainer in the Teaching of Technology, Home Economics and Livelihood Education III (THELE). NVSPC, Bambang, Nueva Vizcaya, 2003.

16. Dellosa, R. M. An Efficient Position Estimation of Indoor Positioning System Based on Dynamic Time Warping International Journal of Advanced Trends in Computer Science and Engineering, Available Online at http://www.warse.org/IJATCSE/static/pdf/file/ijatc se0491.22020.pdf Volume No. 1.2, 2020. 
https://doi.org/10.30534/ijatcse/2020/0491.22020

17. Dionicio, Romualdo E. "Automotive Vacuum Assisted Hydraulic, Parking Brake,And Charging System Simulator.' A Masteral Thesis. Marikina Institute of Science and Technology, Marikina City 2002.

18. Dotimas, Romulo R. The Acceptability of Multipurpose Printed Circuit Booard Electrical Demonstration Trainer in Teaching Elementary Science V, NVSU, Bambang, Nueva Vizcaya, 2004

19. Dumlao, Agustin, Electrical Power Generation and Utilization System: A Feasibility Study, MIST, 1984

20. Esteves, Joey. Basic Electrical Circuit Trainer and Its Effect in the Teaching of Elementary Science and Technology,NVSPC, 1995

21. Ganio, Honorio P. "Study of Automotive Education in Isabela." A Masteral Thesis, Our Lady of the Pillar College, Cauayan City 2000.

22. Mata, K. E., A. Vinluan, A. A. \&Gonzales. D. B., Intelligent Agent Using Artificial Neural Network for E-Service of Bureau of Fire Protection, International Journal of Advanced Trends in Computer Science and Engineering Available Online at http://www.warse.org/IJATCSE/static/pdf/file/ijatc se1091.22020.pdf https Volume 9 No. 1.2, 2020

23. Maur, Arnulfo W. "Development and Validation of a Lettering Device for Instructional Purposes", A Masteral Thesis, NVSPC, Bambang Nueva Vizcaya, 2001

24. Patricio, Carlos V. "Power Train TrainerSimulator: It's Effectiveness in Teaching Automotive Technology". Unpublished Masters Thesis. NVSPC, Bambang, Nueva Vizcaya, 2000.

25. Permitez, Raymond A. "A Transformer Bank Module in Industrial Technology: A Technical Feasibility Study." A Masteral Thesis. Marikina Institute of Science and Technology, Marikina City 2000.

26. Quintal, Satornino N. "Automotive Body Electrical System Trainer: A Technical Feasibility Study." A Masteral Thesis. Marikina Institute of Science and Technology, Marikina City 2002.

27. Rapada, Rodante N. "Development and Validation of Automotive Air-Conditioning Trainer: Its Effectiveness to Instruction". Unpublished Thesis, NVSPC, Bambang, Nueva Vizcaya, 2000.

28. Telen, M. E. \&Guirnaldo, S. A., Blimp Stabilization Controller Optimization using Fuzzy Logic, International Journal of Advanced Trends in Computer Science and Engineering Available Online at http://www.warse.org/IJATCSE/static/pdf/file/ijatc se1391.22020.pdf Volume 9, No. 1.2, 2020 https://doi.org/10.30534/ijatcse/2020/1391.22020
29. Taclobos, Melchor G. "AC Industrial Motor Controller Trainer: A Technical Feasibility Study." MIST, Marikina City 2000

30. Tolentino, Alfredo B. "Quality of Home Economics Instruction in Central Schools of Pangasinan Division II." A Masteral Thesis, Zaragoza Collage, Tayog ,Pangasinan, 2000.

31. Umayam, Henry D. The Effectiveness of a Multipurpose Electrical Demonstration Panel Board for Elementary Grades in Teaching Science and Technology. NVSPC, Bambang, Nueva Vizcaya.

32. TESDA Competency Based Learning Material. Building Wiring Installation NC I \& II.

33. TESDA Competency Based Learning Material. Electrical Installation and Maintenance NC II. 